\title{
Political Repressions \\ in the Tuva People's Republic: \\ Was It Possible to Avoid Them?
}

\author{
Zoia Iu. Dorzhu and Ottuk Iu. Irgit* \\ Tuvan State University \\ 36 Lenin Str., Kyzyl, Republic Tuva, 667000, Russia
}

Received 15.09.2016, received in revised form 29.06.2017, accepted 07.07.2017

This article examines the background and causes of political repressions in Tuva and tries to answer the question, whether it was possible to avoid political repressions. The precondition for the repressions appeared in 1921, in the early days of Tuvan People's Republic (TPR), which received the active support of Soviet Russia. In 1925 students from Tuva were sent to Moscow to study in Communist University of the Toilers of the East (CUTE, also KUTV). Salchak Toka, future leader of Tuva, was one of those students. In 1929 he returned to Tuva and in 1932 he became a general secretary of the Central Committee of the Tuvan People's Revolutionary Party (TPRP). His policy was directed against the former aristocracy and clergy. As a result one of the founders of the TPR Mongush Buyan-Badyrgy was executed. Moreover, Toka tried to make collectivization in Tuva but failed it. His attempts to copy the Soviet experience and his quickly raising in political arena with his fellows from CUTE led to the emergence of the opposition in TPRP. Opposition members wanted to relieve Toka from general secretary post. In 1936 Toka gave full freedom of action to the Interior Ministry to combat against "public enemies" ("the enemies of the people"). In 1938 all opposition members were arrested and executed. But the political repression against the TPR population started just after victory over opposition. Over $8 \%$ from 90,000 TPR citizens became victims of repression. Consequently Salchak Toka's actions led to the emergence of the cult of personality in Tuva. We cannot answer "No" to question "Was it possible to avoid political repressions in Tuva?" because repressions against political opposition were inevitable. But if we ask question "Was it possible to avoid massive repressions in Tuva?" answer "No" becomes possible, because Toka could finish repressions after defeating his political enemies.

Keywords: Tuva People's Republic, opposition, counterrevolution, repressions, Tuva People's Revolutionary Party, cult of personality, rehabilitation.

DOI: 10.17516/1997-1370-0104.

Research area: national history.

The period of the Tuva People's Republic (TPR) (1921-1944) is one of the most important periods of its history as Tuva was an independent state, had its own Constitution, flag, Coat of
Arms, currency, confirming its sovereignty. Despite the all-round support from the Soviet Union, during 23 years of its history TPR's orientation to the Soviet model of development

(C) Siberian Federal University. All rights reserved

* Corresponding author E-mail address: zoyadorzhu@yandex.ru; irgit_06x@mail.ru 
expressed loyalty, being rather an ally to the USSR than its "marionette". This period of Tuvan history has many "blind spots", among which a special place is occupied by political repression. At the moment, one of the most urgent scientific and social problems of the modern history of Tuva is the study of the mass repression policy in the 1930-40s, as these repressions affected many residents of the republic, although the number of victims of political persecution is unknown so far. When we looked into archival documents, it turned out that the number of politically repressed is 1,034 people (Dostak-ool, 2003: 5). According to the Prosecutor's Office of the Republic of Tuva, there are data for 1,286 people who were arrested and punished for their political views and convictions. If we take into account numerous applications of citizens to learn more about their repressed relatives who were not included in this list, the number of victims of political repressions will become much larger' ${ }^{1}$. In the opinion of M.B. Dostak-ool, the Memorial Society a member, the population of the TPR in that period did not exceed 90 thousand people, and about $8 \%$ of the Tuva total population was subjected to mass political repression (Dostak-ool, 2003: 6).

However, to this day political repressions in Tuva have not become the subject of a special scientific study yet. This is due to the fact that most archival materials concerning repression have not yet been published and remain closed for use. In addition, for many people affected by repression and their descendants this problem is still too "acute" and painful, which also hinders the objective analysis of these events. These or other aspects of this problem were reflected in a number of newspaper publications, in collections of papers, or were mentioned in passing as being a part of scientific research on another subjects of the Tuva People's Republic period. These are M.B. Kenin-Lopsan's novel-essay "BuyanBadyrgy" (2000), dedicated to the life and activities of the last ruler of Tuva, shot during the repression, M.B. Dostak-ool's book "The cult of personality and political repression in Tuva" (2003) and "Salchak Toka" (2016), published by the team of authors - N. Mollerov, A. Kanzai, G. Shirshin. Nevertheless, this topic is far from exhausted. Recently, the terrible mysteries of the time have come up, thereby increasing the importance of this problem.

The purpose of this article is to study the history of the political development of TPR, the causes and conditions of mass repressions in the 1930 s and 1940s, and try to answer the question, whether it was possible to avoid repression.

Political repressions in Tuva are primarily connected with the influence of the Soviet Union on its political and ideological development. Therefore, despite the decade of struggle against the feudal system legacy and the persecution of former representatives of the nobility and the clergy, the repressive policy in TPR was particularly strong in the years of the Great Terror, specifically in 1936-1938, when inner-party purges of "right" with opposing views and pro-Soviet "left". The trial of 1938, known as the "case of nine", marked the beginning of a large-scale repressive policy throughout the territory of TPR, involving all classes of the population. Repressions stroke a blow not only at the representatives of the former nobility, clergy, and oppositionists, but also at ordinary arats. Denunciations or intimidation of innocent people led to their persecution, stigmatization as "enemies of the people", deprivation of liberty; some were sent to execution, being accused of "espionage" and counter-revolutionary activities.

One of the first works on the political and legal underpinnings of repressive politics is the cycle of articles by the leading researcher of the Tuvan recent history Iu.L. Aranchyn "Long way to the truth (on the history of the Tuva trial in 1938)". The articles were published in Russian 
in the newspaper "Tuvinskaia Pravda" in 1990 (Aranchyn, 1990), then in 1991 they were translated into Tuvan for the newspaper Shyn (Aranchyn, 1991: 2). The author of the articles considered the factors and causes of the 1938 repression on a broad historical background, beginning with the first years of the TPR creation and ending with the inner-party struggle for power between two "left" and "right" factions.

In many respects the historiography of TPR political repressions is based on the Aranchyn's research. Despite the articles' relative politicization, since they were written back in the Soviet years and remained loyal to socialist ideology, they examined in detail the influence of the personality cult of S. Toka on the party and TPR state administration system, the fight against political opposition and the consequences of mass repression in Tuva. As in the case of Aranchyn's work, we reckon it necessary to consider the history of TPR political repression in the context of its entire history.

The Uryanghai Territory, as Tuva was called until 1921, had been under the yoke of major powers for seven centuries, until the second half of the $18^{\text {th }}$ century. It was a part of the Mongolian state, and in the period from 1758 to 1912, it was a part of the Qing Empire. After the Xinhai Revolution and the fall of the Manchu dynasty, Tuva freed itself from Chinese oppression. Then it had to choose either to become a part of independent Mongolia, or to seek the support of the Russian Empire, taking into consideration that Tuvan arats had already developed friendly relations with the population at the Russian border. In 1914, Emperor Nicholas II gave the go-ahead to the letter of Mongush Buyan-Badyrgy on Tuva's accession to Russia's protectorate (Tyva, 1994: 22).

On August 13-15, 1921, after the revolutionary events and the civil war in Russia, on the initiative of the noion Daa-kozhuun Mongush
Buyan-Badyrgy and the Russian philanthropist I.G. Saf'ianov the settlement of Sug-Bazhy (now Kochetovo) saw all-Tuva constituent Khural. It was attended by 62 representatives from 7 kozhuuns of the Uryanghai Territory and a Soviet delegation of 17 people, which included I.G. Saf'ianov and S.K. Kochetov, who commanded a detachment of red partisans during the Civil War. The result of the Khural was the creation of a sovereign state - the Tuva People's Republic and the adoption of Constitution drawn up under the leadership of Buyan-Badyrgy. At the same time, the Khural participants recognized the important role of Soviet Russia in the creation of an independent state ${ }^{2}$.

Soviet Russia, in turn, sought to strengthen its influence in the young republic, so one of the first tasks was the creation of a revolutionary party in Tuva. As early as 1921, the commissioner of the Comintern in Tuva B.Z. Shumiatskii recommended Saf'ianov to help the TPR government in creating the party. The work on the party creation was led by Oiun Kursedi and the arats of the Oiunnar kozuun. The first congress of the Tuvan People's Revolutionary Party (TPRP) was held from February 28 to March 1, 1922, attended by 40 delegates, mainly from western and central kozhuuns. At the second congress, which took place in the summer of 1923, the number of delegates was 568 people out of five kozhuuns, and in 1925 there were 7,000 delegates from all 6 kozhuuns. From the very beginning of its existence, the TPRP yearned to play a leading role in the country and was gathering the arats, gradually developing among them the idea of a struggle against the "exploiters", against the former nobles and clergy, who constituted the first officials of the young state (Aranchyn, 1982: 21-24).

Animportantrole in theyoung state formation was played by the Russian self-governing labor colony (RSLC), which actively engaged in TPR's 
cultural and educational activities, facilitated the opening of schools, the development of science, medicine, art, etc. The most critical part in the TPR political development was the July 1924 issue of the newspaper "Krasnyi Pakhar", which was positioned as a paper for workers and peasants, a spokesman and an expresser of the will of proletarian public opinion (Chadamba, 2014: 2).

In 1925, the first group of Tuvan students was sent to Moscow to study at the Communist University of the Toilers of the East named after I.V. Stalin (CUTE), among whom was the TPR future leader, one of the main organizers of the mass political repressions S. Toka. The CUTE was organized under the People's Commissariat for Nationalities with the purpose to train the leading cadres of the national republics from the representatives of the nationalities themselves and to spread the communistic ideas to the East. This university played a dramatic role in the training of the Tuvan intelligentsia and the party elite (Kharunov, 2014: 2).

After graduating from the CUTE in 1929, S.K. Toka returned to Tuva and, thanks to the support of the RSLC, immediately took an important place on the political Olympus of the young state. He began agitating the class struggle against former representatives of the nobility and the clergy, purging the party ranks and state officials from the "exploiters". As early as in October 1929, 16 former party and government leaders were arrested, among them was Mongush Buyan-Badyrgy, the founder of the Tuvan statehood, the Chairman of the first Tuva Government. In the same year, all representatives of the nobility and the clergy were deprived of their suffrage. On March 22, 1932 at a meeting of the TPRP Central Committee it was decided to apply the highest penalty (death through execution by a firing squad) to the "exploiters". Suspects of counter-revolutionary activities Buyan-Badyrgy,
Donduk, Shagdyr and Bondu were sentenced to death penalty without trial and investigation, and on March 23 the verdict was carried out. This was the first round of political repressions in Tuva, held under the slogan of dekulakization of the nobility and the clergy, so they did not have a mass character, as in subsequent years.

Mongush Buyan-Badyrgy and other victims of the 1929 repressions - Mongush Shagdyr, Boidu, Sanchai-Dorzhu, Narmandagy, Shagdyr, Danzyryn, Sagdy, Baazan, Chamyian, Dala-Surun, Samdan, Sonam, Kileiti, Sundui, Dungulak, Nima-chap, Dembirel were rehabilitated only 75 years after their death. The decree on this "On the political rehabilitation of statesmen of the Tuvan People's Republic and citizens subjected to political repression in the Tuva People's Republic in the 1920s-1930s" was signed by the Republic Head in $2007^{3}$. It was decided to erect in the Republic's capital a monument to Buyan-Badyrgy, the founder of the Tuvan statehood and one of the main initiators of the Uryanghai Territory's accession under the auspices of Russia. The monument was opened in 2014, celebrating the centenary since the unification of Russia and Tuva, thereby commemorating the memory of this amazing man (Philatenko, 2014: 3).

One of the main reasons for the class struggle against the "right" was not only the Tuva Sovietization, but also the aggravation of relations between the arats and the more prosperous classes of the population in the course of the unsuccessful collectivization concerning the TPR economy and several uprisings, among which there was Khemchik one in 1924, organized by the pro-Mongolian nobility. In 1930s and 1932 two more uprisings against collectivization and dekulakization took place in Dzun-Khemchik and Kungurtug, which the TPRP authorities actively used in their struggle against the "right". 
In the summer of 1932, the General Secretary of the TPRP Central Committee Irgit Shagdyrzhap got seriously ill, and the second secretary, S.K. Toka soon assumed his post. This event, according to M.B. Dostak-ool, became the starting point of the undivided dictatorship of Salchak Toka in Tuva, which lasted until his death in 1973 (Dostak-ool, 2003: 118). The same opinion is shared by journalists M.S. Bayir-ool and A.A. Dugerzhaa in their articles on Tuva repressions.

Having become the General Secretary of the TPPR Central Committee, Toka began to gather around him like-minded people, primarily the CUTE graduates, who fully supported the development of the young state by the Soviet model. Among them were Khertek Anchimaa, Sedip-ool Tanov, Oiun Polat, Tatiana Kamova, Khovalyg Bazyr-Sat and others. Rapid progress to the tops by S.K. Toka and his associates, who were called "kutvans" (from CUTE - KUTV in Russian) and who followed the Soviet policy of collectivization blindly and unsuccessfully, aroused dissatisfaction among other TPRP members. The latter supported the independent TPR development, taking into account the mentality, culture and lifestyle of the Tuvinians. So by 1936 the opposition was formed, headed by prominent politicians Sat Churmit-Dazhy, AdygTiuliush Khemchik-ool and Kara-Sal Pirinlei. They wanted to lower Toka from the post of TPRP General Secretary to the Minister of Culture and appoint General Secretary either Oiun Danchai, Chairman of the State Bank, or Sat Lopsan, the Minister of Trade and Industry of the TPR.

In response to the plot against him, Toka appointed his closest follower Oiun Polat as the Minister of Internal Affairs of the TPR (1936), instructing him to control the oppositionists and, at the right time, get rid of them. According to the memoirs of Oiun Polat himself, Toka significantly expanded the functions and powers of the
Ministry of Internal Affairs, thereby launching a powerful repressive machine that later struck the entire population of Tuva (Polat 1991: 3). Polat communicated effectively with M.P. Frinovskii, the First Deputy Minister of the Ministry of the Internal Affairs of the USSR, in order to learn the experience of fighting counter-revolution in Soviet Russia and create a system of identifying "enemies of the people" in Tuva.

The first to be arrested was the TPR prosecutor Kara-Sal Pirinlei in December 1937; the head of the "counter-revolutionary Trotskyist espionage organization" was arrested in February 1938. Chairman of the TPR State Bank Oiun Danchay was one of those whom the opposition planned to elect the TPRP General Secretary instead of Toka. Until the end of August 1938, other "counter-revolutionaries" were also arrested: excluded from TPRP Kuzhuget Seren, the Minister of Trade and Industry Sat Lopsan, the Director of State Printing House Khovalyg Totkan, the TPR Prosecutor's Deputy Oiun Sengiijik, the Secretary of the Small Khural Presidium Kuular Sungar-ool. On 30 August, there were arrested the rest of the opposition organizers - the TPR Minister of Foreign Affairs Sat Churmit-Dazhy and the Chairman of the Small Khural Presidium Adyg-Tiuliush Khemchik-ool.

At the Third Plenary Meeting of the TRP Central Committee on August 30-31, 1938, Salchak Toka made a special report, in which S. Churmit-Dazhy, A.-T. Khemchik-ool, O. Danchai and their followers were accused of counter-revolutionary activities with the aim of overthrowing the arats' power, restoring the feudal system and annexing Tuva to imperialist $J_{a p a n}{ }^{4}$. The resolution of the Plenum indicated the need to apply to the "enemies of the people" the highest penalty, i.e. the death penalty". Thus began the trial, which entered the Tuva history of as "the case of nine". 
The next step against this group of conspirators was calling the Extraordinary Open Court of the Small Khural Presidium on October 10-13, 1938. The work of the court was fully covered in the periodical press, journalists did not hesitate to demand the execution of the defendants, as a consequence the defendants' families were publicly persecuted. The court passed a verdict - the death penalty to all nine people with the full confiscation of their property (Dostakool, 2003: 134). Shortly before the execution of the verdict, for Kuzhuget Seren and Khovalyg Totkan, who after lengthy interrogations and tortures confessed their guilt and gave false testimony against other convicts, the capital punishment was replaced by imprisonment for 8 years. The verdict over the other convicts was carried out on October 16, 1938. According to Mongush Baiyr-ool, the 1938 trial was nothing more than a farce; under the guise of fighting the "enemies of the people" it was an ordinary struggle for power and the establishment of the dictatorship and personality cult of Salchak Toka (Baiyr-ool, 2008: 3). This case was reviewed by the Prosecutor General's Office of the RSFSR twenty-six years later, on September 3, 1964. The case revealed the grossest violations of the law: the use of torture during the investigation, the falsification of investigation materials. There was no objective evidence of guilt in counterrevolutionary activity and in separatism; all the allegations were based on verbal confirmation of the accused, who after lengthy torture agreed with the charges brought against them. The witness of the cruel torture was Kuzhuget Seren, a survivor of the "case of nine", who was forced to give false testimony against the other defendants. The Judicial Collegium for Criminal Cases of the Supreme Court of the RSFSR, by its decision of December 3, 1964, annulled the verdict, thereby rehabilitating all the accused in the "case of nine" (Dostak-ool, 2003: 88-90).
As one can see, the rehabilitation of innocent convicts did not happen immediately. The repressive machine launched in 1936 and after a successful fight against the "enemies of the people" it received complete freedom of action and many residents of the republic became victims of repression in the next two decades, until 1953.

The question arises here whether political repression could have been avoided. It is difficult to give an unambiguous answer to this question. The TPR political development through the Soviet system, the struggle against the opposition and the ideological influence of the party, the pursued policy of the class struggle by all means would have led to persecution of representatives of the nobility, the clergy and the opposition. But if the question is asked differently, whether it was possible to avoid mass repression, then the probability of an unequivocal answer becomes larger. The "successful" struggle against political enemies, with pro-Soviet leaders led to the freedom of action for the repressive apparatus of the TPR Ministry of Internal Affairs and to violations of the law and human rights. The repressions spread to the broadest strata of the population and acquired a mass character. If at that time there had been at least some restrictions on violations of the rule of law and human rights, on the influence of the party apparatus as regards the organization and implementation of repression, the number of victims could have been significantly less.

Until now, there has been no authoritative general statistics on the number of convicts and the repressed political and other leaders in the 1930s and 1940s, on the repressed from the people's revolutionary army and "unreliable" cadres from other spheres of Tuvan society. The rehabilitation policy of the repression victims requires thorough scientific analysis, taking into account that moral and physical suffering affected not only the repressed, but also their 
relatives and friends. The "enemies of the people" name stigmatized innocent people and entire families. Many people died as a result of terror and false accusations. Painful lessons and experience of the national drama, an attempt to look into its nature - these problems strongly need the research and objective assessment based on an analysis of negative and positive facts.

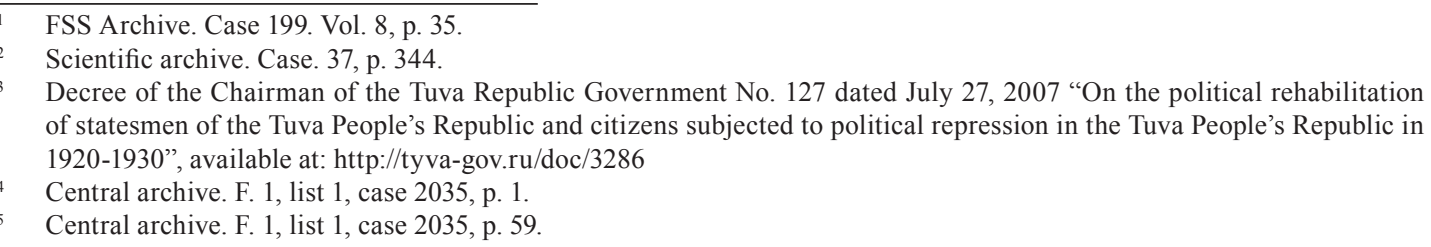

\section{Words explanation}

Kozhuun - a Tuvan administrative and territorial unit.

Noion - a representative of the Tuvan aristocratic nobility.

\section{List of abbreviations}

Scientific archive - Scientific Archive of the Tuva Institute of Humanitarian and Applied Social and Economic Research at the Tyva Republic Government.

FSS archive - Archive of Directorate of Federal State Security Service of the Russian Federation in the Tyva Republic.

Central archive - Center of archival documents of parties and public organizations of the Central State Archive of the Tyva Republic.

\section{References}

Aranchyn, Iu.L. (1982). Istoricheskii put' tuvinskogo naroda k sotsializmu [Historical path of the Tuvan people to socialism]. Novosibirsk, 21-24.

Aranchyn, Iu.L. (1991). Onza azhyk sudche oruk: Tuva uzhen chyldarga repressiiaga taiaryshkannarnyn salym-cholunun dugaiinda. In Chyn [The Truth], 27-36.

Aranchyn, Iu.L. (1990). Dolgii put' k pravde: k istorii vozniknoveniia sudebnogo protsessa 1938 goda v Tuve [Long way to the truth: On the history of the Tuva trial in 1938], In Tuvinskaia pravda [The Tuvan truth], 28-30, 35-36, 38-39, 41-44, 46-50.

Baiyr-ool, M.S. (2008). Repressii: Kogda i kak oni nachalis'? [Repressions: when and how did they begin?], In Tuvinskaia pravda [The Tuvan truth]. Kyzyl, 140 p.

Chadamba, E.L. (2014). Krasnyi Pakhar', 20-e gody XX veka [Red Pakhar, the 1920s], In Tuvinskaia pravda [The Tuvan truth]. Kyzyl, 68 p.

Dostak-ool, M.B. (2003). Kult' lichnosti i politicheskie repressii v Tuve [Cult of personality and political repressions in Tuva]. Kyzyl, 144 p.

Kharunov, R.Sh. (2014). KUTV - kuznitsa kadrov mirovoi revolutsii [CUTE - source of cadres for the World revolution], In Tuvinskaia pravda [Tuvan truth]. Kyzyl, $46 \mathrm{p}$.

Philatenko, A.G. (2014). Buian-Badyrgy vybral Rossiiu [Buyan-Badyrgy chose Russia], In Tuvinskaia pravda [The Tuvan truth]. Kyzyl, 100.

Polat, O.O. (1991). Ia ne v otvete za Toka: o sudebnom protsesse $1836 \mathrm{~g}$. v TNR [I'm not responsible for Toka: on the 1938 trial in Tuvan People's Republic]. In Molodezh' Tuvy [The Youth of Tuva].

$$
-963-
$$


Tyva. (1994). Ustanovlenie pokrovitel'stva Rossii nad Tuvoy v 1914 godu [The establishment of the Russian protection of Tuva in 1914]. Kyzyl.

\title{
Политические репрессии \\ в Тувинской Народной Республике: \\ можно ли было их избежать?
}

\author{
3.Ю. Доржу, О.Ю. Иргит \\ Тувинский государственный университет \\ Россия, 667000, Республика Тыва, Кызыл, \\ ул. Ленина, 36
}

\begin{abstract}
Авторы статьи исследуют предпосылки и причины политических репрессий в период Тувинской Народной Республики (1921-1944), пытаются выяснить, можно ли было избежать массовых репрессий. Предпосылки для репрессий возникли ещзё в 1921 г., когда Тувинскую Народную Республику (ТНР) активно поддержсивала Советская Россия. В 1925 г. первая группа студентов-тувинцев была направлена в Москву для обучения в Коммунистическом университете трудящчихся Востока им. И.В. Сталина (КУТВ), среди которых был и будущчий руководитель ТНР, один из главных организаторов массовых политических репрессий С. Тока. Окончив КУТВ в 1929 г., С.К. Тока вернулся в Туву и в 1932 г. стал генеральныл секретарем Тувинской народно-революиионной партии. В 1929 г. все представители знати и духовенства были лишены избирательного права, был казнен основатель партии Монгуш Буян-Бадыргы. С. Тока также безуспешно проводил политику коллективизации. Его попытки продвинуть своих сокурсников по КУТВ вызвали оппозиционные настроения в партии вплоть до попытки заговора с целью сместить С. Тока с поста генсека. В 1936 г. С. Тока предоставил МВД Тувы полное право вести борьбу с «врагами народа». В 1938 г. были арестованы и казнены все члены оппозиции, и начались репрессии против жителей ТНР. Пострадало $8 \%$ из 90-тысячного населения. Действия С. Тока привели к возникновению культа личности в ТНР. Мы не можем ответить отрицательно на вопрос, возможно ли было избежать политических репрессий в ТНР, так как борьба с оппозицииеи неизбежна. Но если сформулировать вопрос иначе: «Можно ли было избежать массовых репрессий?», то вероятность ответа «Нет» становится больше, так как С. Тока мог прекратить репрессии после расправы с непосредственными врагами.
\end{abstract}

Ключевые слова: Тувинская Народная Республика, оппозицуия, контрреволюция, репрессии, Тувинская народно-революичонная партия, культ личности, реабилитация.

Научная специальность: 07.00.02 - отечественная история. 